\title{
ASSESSMENT OF CARBON FOOTPRINT AND LIFE CYCLE COSTS OF WINTER WHEAT (TRITICUM AESTIVUM L.) PRODUCTION IN DIFFERENT SOIL TILLAGE SYSTEMS
}

\author{
HOLKA, M. \\ Department of Agricultural Production Systems, Institute for Agricultural and Forest \\ Environment, Polish Academy of Sciences, Bukowska 19, 60-809 Poznań, Poland \\ (e-mail: malgorzata.holka@isrl.poznan.pl; phone: +48-618-475-601) \\ (Received $5^{\text {th }}$ Mar 2020; accepted $10^{\text {th }} \mathrm{Jul} 2020$ )
}

\begin{abstract}
It is essential to identify the environmental impact of crop production with different soil tillage systems and to find solutions for reducing greenhouse gas emissions if we are to develop low-carbon agriculture. The aim of the study was to assess and compare the carbon footprint and costs of winter wheat production in different soil tillage systems using a life cycle approach. The winter wheat production in three soil tillage systems: conventional tillage, reduced tillage and direct sowing was analysed. The study was conducted in 2015-2017 on 15 farms in the Wielkopolska region (Poland). Inclusion of carbon sequestration into the assessment of carbon footprint allowed for a considerable reduction of the net global warming potential associated with wheat production in unploughed tillage systems. The highest average cost of wheat production per one tonne grain yield was found in reduced tillage. Conventional tillage was associated with the highest costs and greenhouse gas emissions in soil cultivation and sowing, mainly due to a higher fuel consumption and more intensive use of agricultural machinery in comparison to systems with reduced tillage and direct sowing. Pre-farm production linked with the direct input levels contributed mostly to a high overall cost of winter wheat production in the analysed tillage systems.
\end{abstract}

Keywords: agriculture, climate change, eco-efficiency, carbon sequestration, grain crop

\section{Introduction}

Certain amounts of raw materials and energy are consumed in agriculture for production purposes, having adverse effects on the environment such as air, water and soil pollution (Kanianska, 2016). The release of nitrous oxide $\left(\mathrm{N}_{2} \mathrm{O}\right)$, methane $\left(\mathrm{CH}_{4}\right)$ and carbon dioxide $\left(\mathrm{CO}_{2}\right)$ contributes to the enhanced greenhouse effect (UNEP, 2010). This is a major concern due to changing climate conditions (Cihelková, 2011). It is estimated that the share of food systems in global anthropogenic greenhouse gas (GHG) emissions amounts to 19-29\% and agricultural production contributes approximately $80 \%$ of the total food system emissions (Vermeulen et al., 2012). In the European Union (EU), the agricultural sector is responsible for $10 \%$ of the total GHG emissions (EEA, 2019). According to the EU Action Plan for achieving the reduction of gaseous pollutants, agriculture, as one of the economic sectors not covered by the EU Emission Trading System, must cut its GHG emissions by 30 percent by 2030 based on 2005 figures (EC, 2014). Mitigation and adaptation to climate change are important challenges facing crop production (Loboguerrero et al., 2019). Farmers, in efforts to achieve the best possible production and economic results must take into account the need to protect the environment including the issue of climate change (Liu et al., 2016). Therefore, it is essential to search for solutions and ways to prevent the depletion of natural resources and reduce the emissions of harmful substances related to crop production (Beddington et al., 2012; Campbell et al., 2016). 
Conventional, traditional tillage based on soil inversion by plough is a dominant soil tillage system. However, there is growing interest in unploughed tillage systems. The share of arable land on which non-inversion tillage systems were practised in Poland was 9\%, while in the EU it reached 26\% (CSO, 2012; Eurostat, 2018). The scientific literature relating to the soil tillage systems indicates that abandoning ploughing does not only lead to savings in labour cost, energy expenditure and time on soil preparation for sowing but also has positive influence on physical, chemical and biological soil properties (Morris et al., 2010; Vach et al., 2016). There is a wide range of agricultural machines available on the market that contributes to a growing tendency towards the unploughed tillage systems, particularly in the case of large, commercial farms. They are able to afford the purchasing cost of high-powered tractors and specialized agricultural equipment designed for the soil preparation without ploughing (Wandel and Smithers, 2000). The use of modern multi-task machines performing simultaneously the operations of soil tillage, fertilizer application and sowing enables to decrease tillage depth and reduce the number of tillage operations. Due to the fact that fuel consumption is lower, this is considered the most important way to obtain lower GHG emission and costs (Guardia et al., 2016; Townsend et al., 2016).

GHG emissions are generated at various stages of the life cycle of agricultural products. Apart from agricultural operations, off-farm processes such as extraction of raw materials, manufacture of agricultural production means, transport, use and final disposal are also potential GHG emission sources (Cooper et al., 2011; Moudrý et al., 2013a). The total amount of GHG emission resulting from all processes throughout the crop life cycle can be evaluated with the carbon footprint indicator (Pandey et al., 2011). It reflects the potential impact on global warming throughout the life cycle of a product or a process, allowing one to determine ways to reduce the negative impact (Weidema et al., 2008; BSI, 2011). Regarding the impact of the agricultural production on the carbon footprint, the soil organic carbon sequestration needs to also be taken into consideration (Hillier et al., 2009).

Wheat (Triticum aestivum L.) is one of the most important food crops. It occupies the third place in the world cereal production, after maize (Zea mays L.) and rice (Oryza sativa L.) and the first place in terms of cereal crop area (FAO, 2019). Research on both environmental and economic effects of wheat production, depending on tillage practices is important for achieving more environmentally friendly food production. In order to have a comprehensive comparison of soil tillage systems, the whole life cycle of the crop should be taken into account. The aim of the study was to determine the carbon footprint and life cycle costs of winter wheat grown with different soil tillage systems.

\section{Materials and Methods}

\section{Study sites}

The research was carried out on 15 agricultural farms, located at $51^{\circ}-52^{\circ}$ north latitude and $15^{\circ}-19^{\circ}$ west longitude in the Wielkopolska region, Poland (Fig. 1), during two consecutive growing seasons $2015 / 2016$ and 2016/2017. The selection of farms was made with an expert advisory based on the information resources of the Wielkopolska Agricultural Advisory Centre (WAAC) in Poznan. The cooperation with the agricultural advisers of WAAC has allowed to select the farms best reflecting the criterions adopted for the research regarding to winter wheat production under three soil tillage systems: 
conventional tillage (CT), reduced tillage (RT) and direct sowing (DS). There were five farms chosen in each of three groups of farms representing particular soil tillage systems. The description of studied farms is presented in detail in Table 1. Data for analyses were gathered through face-to-face interviews with the farmers using a prepared questionnaire.

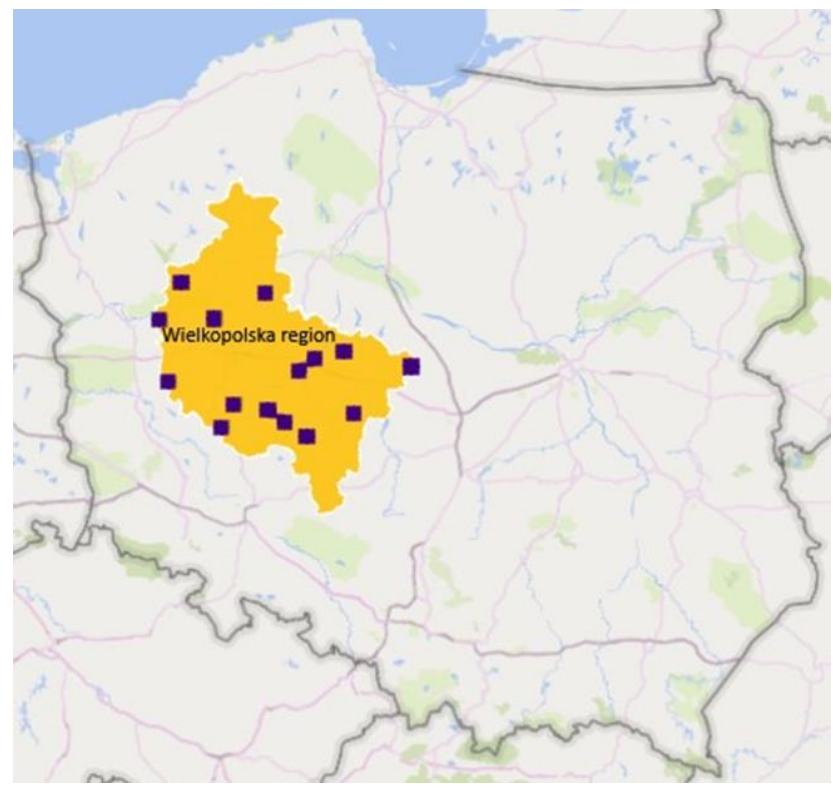

Figure 1. Location of studied farms in the Wielkopolska region

Table 1. Characteristics of studied farms representing wheat production under conventional tillage $(C T)$, reduced tillage $(R T)$ and direct sowing $(D S)$ systems (averages from the study years with min-max range in parentheses)

\begin{tabular}{c|c|c|c}
\hline Specification & CT & RT & DS \\
\hline Number of farms & 5 & 5 & 5 \\
Utilised agricultural area (ha) & $35.2(7.8-73.1)$ & $69.4(18.5-156.3)$ & $316.0(44.5-975.0)$ \\
Share of arable lands (\%) & $92.4(77.0-100.0)$ & $99.4(98.0-100.0)$ & $94.0(82.3-100.0)$ \\
Share of permanent grasslands (\%) & $7.6(0.0-23.0)$ & $0.6(0.0-2.0)$ & $6.0(0.0-17.7)$ \\
Livestock density (LSU ha $\left.{ }^{-1}\right)$ & $0.6(0.0-1.0)$ & $0.3(0.0-1.1)$ & $1.6(0.0-4.9)$ \\
Cropping pattern (\%) & & & \\
- cereals & $85.1(65.5-100.0)$ & $62.0(39.9-76.7)$ & $66.4(37.4-100.0)$ \\
- industrial crops & $12.9(0.0-26.7)$ & $29.4(21.4-40.5)$ & $15.1(0.0-49.4)$ \\
- feed plants & $1.1(0.0-11.2)$ & $1.6(0.0-9.1)$ & $16.3(0.0-62.6)$ \\
- other plants & $0.9(0.0-7.2)$ & $7.0(0.0-20.8)$ & $2.2(0.0-16.7)$ \\
- catch crops & $11.5(0.0-23.0)$ & $27.0(0.0-45.9)$ & $19.7(0.0-40.2)$ \\
\hline \multicolumn{2}{|r}{}
\end{tabular}

In the studied farms, CT included post-harvest tillage operations, ploughing to $25-30 \mathrm{~cm}$ depth and soil preparation before wheat sowing. For deep or shallow RT, instead of a plough, the most commonly tillage machine used was a disc cultivator or a cultivator with rigid tines. In turn, if DS system was practiced, the seeds were placed directly into the untilled soil with crop residues using a specialist direct seed drill. Figure 2 presents winter wheat cultivation in three tillage systems. The average grain yields per hectare were 7.6, 6.9 and 6.6 tonnes in CT, RT and DS, respectively. 


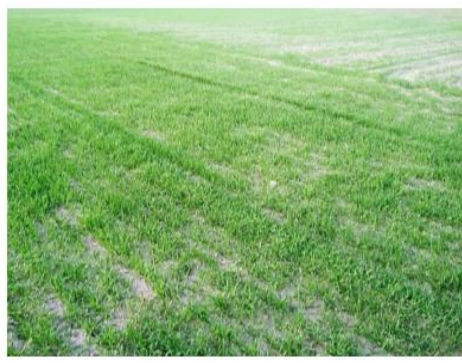

a

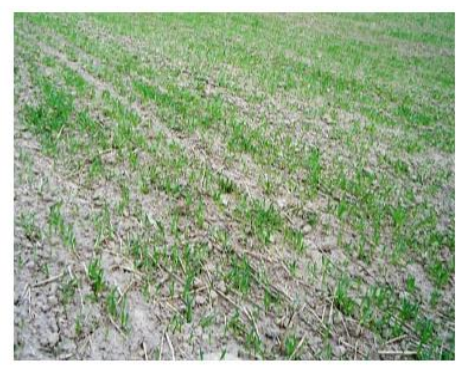

$\mathrm{b}$

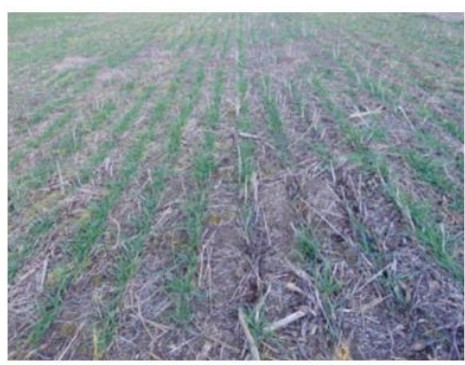

C

Figure 2. Winter wheat cultivation in conventional tillage (a), reduced tillage (b) and direct sowing $(c)$

\section{Carbon footprint}

The total amount of GHG emission from the life cycle of winter wheat production under different soil tillage systems was determined with the carbon footprint indicator whose value is expressed in $\mathrm{CO}_{2}$ equivalent. Carbon footprint was calculated according to the life cycle assessment (LCA) methodology that consists of the four phases: 1) the goal and scope definition, 2) the life cycle inventory analysis (LCI), 3) the life cycle impact assessment (LCIA), with the following steps: the selection of impact categories, category indicators and characterisation models, the assignment of LCI results (classification) and calculation of category indicator results (characterisation), 4) the interpretation of results (PKN, 2006, 2009; Caffrey and Veal, 2013).

\section{Goal and scope}

The goal of this study was to compare the carbon footprint of wheat production in different soil tillage systems. The system boundaries were from "cradle-to-farm gate", i.e. from the manufacturing of means of agricultural production to the processes of crop cultivation and harvesting (Fig. 3). Two phases of the life cycle, namely the pre-farm production and farm production were distinguished within the studied system. The first phase as the background included manufacture, transportation and delivery of means of agricultural production (fuel, agricultural machinery, agrochemicals, seeds etc.) to the farm gate. The farm production constituting the foreground system concerned the crop production processes as: soil cultivation, sowing, fertilization, plant protection and harvesting. The functional unit chosen was 1 tonne of wheat grain.

\section{Life cycle inventory}

In order to perform the LCA analysis, the following data were obtained from the farms: the characteristics of fields under winter wheat cultivation, the yields and detailed information on wheat production technology including type and duration of field operations, characteristics and technical specifications of agricultural machinery used, consumption of seeds, fertilizers, plant protection products, fuel and lubricants. It was assumed that the mass of spare parts constituted $30 \%$ of the mass of machinery used and the mass of repairs materials constituted $4 \%$ of mass of spare parts (Harasim, 2002). Consumption of lubricants was set to $4 \%$ of the consumption of fuel (Harasim, 2002). 


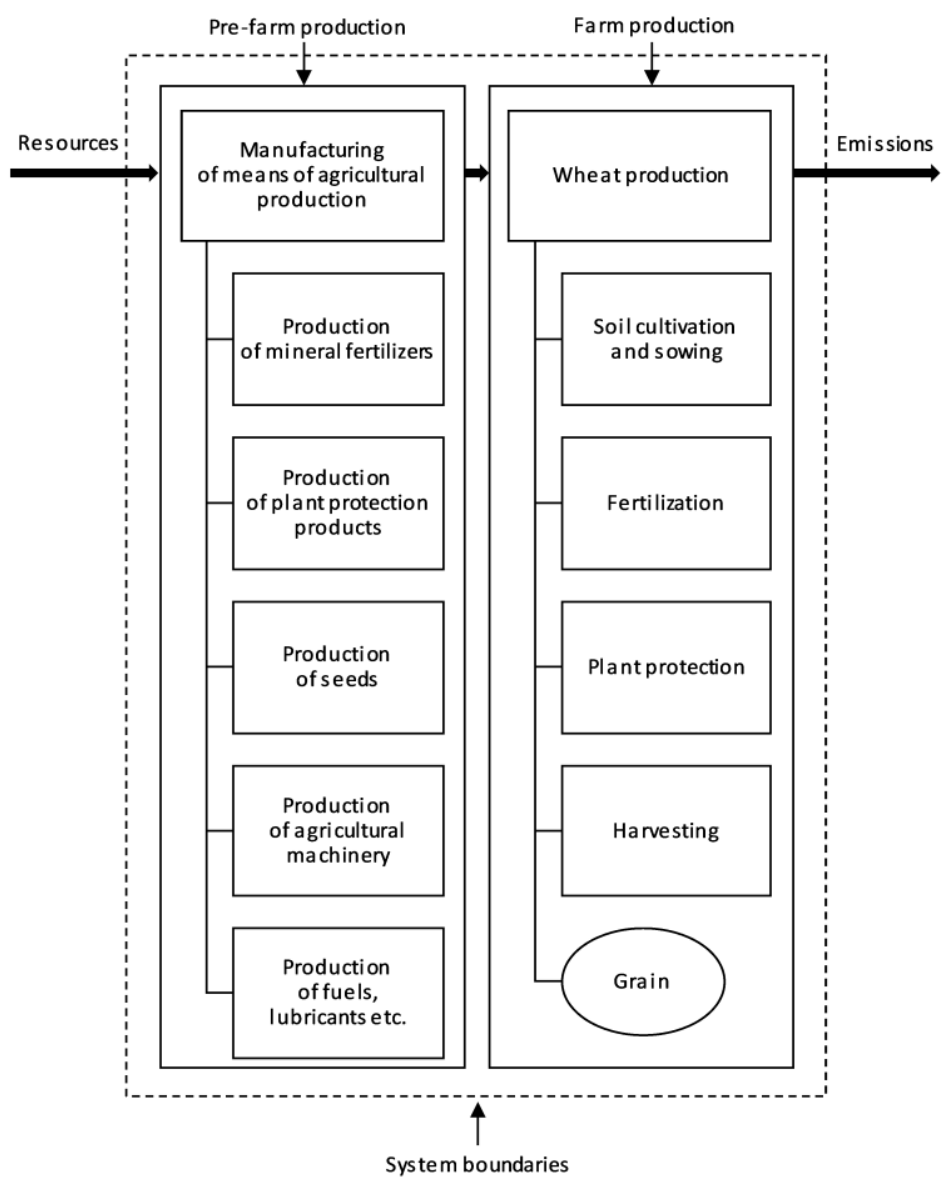

Figure 3. System boundaries diagram of the life cycle of wheat production from "cradle-tofarm gate"

During the second LCA phase (LCI), for each considered soil tillage system in winter wheat production, the energy and material inputs as well as the environmental emissions that contribute to the greenhouse effect were identified and calculated quantitatively per functional unit of $1 \mathrm{t}$ of grain. Data on the amounts of synthetic fertilizers applied and the emission factors depending on the types of fertilizers given by the EMEP guidebook (EEA, 2013) were used to estimate the direct and indirect $\mathrm{N}_{2} \mathrm{O}$ emissions from the mineral fertilization. Calculations of $\mathrm{N}_{2} \mathrm{O}$ emission from crop residues were based on the methodology provided by the Intergovernmental Panel on Climate Change (IPCC, 2006). The emissions related to nitrate leaching were estimated in accordance with a method adopted by van Beek et al. (2003). Emissions from fuel combustion were estimated based on the amounts of fuel consumption in field operations according to the EMEP guidebook (EEA, 2016). For inclusion of soil organic carbon (SOC) changes in LCA, the assessment of the SOC sequestration potential in a 100-year perspective was performed (Petersen et al., 2013). The carbon inflows from crop residues of winter wheat as well as catch crops and soil tillage system were taken into account in this approach. The data source for inventory of background processes such as production of agrochemicals and agricultural machinery was the Ecoinvent version 3.0 database (Swiss Centre for Life Cycle Inventories) used with the TEAM version 5.3 software (PricewaterhouseCoopers - Ecobilan). 


\section{Life cycle impact assessment and interpretation}

The life cycle impact assessment was performed using the CML (Center of Environmental Science of Leiden University) methodology, based on a midpoint approach. The IPCC data were used for the estimation of the global warming potential (GWP) in a 100-year time horizon (Guinée et al., 2002; IPCC, 2007). The formula for calculating the carbon footprint indicator is given in Equation 1 (Kowalski et al., 2007).

$$
\text { Carbon footprint }=\sum_{i} m_{i} \cdot G W P_{a, i}
$$

where: $m_{i}$ - the quantity of the substance $i$ emitted (in kg per functional unit), GWP $P_{a, i}-$ the global warming potential for a substance $i$ over a time horizon $a$ (expressed relative to $\mathrm{CO}_{2}$ per $\mathrm{kg} i$ ).

In order to broaden the interpretation of the obtained results and to investigate the influence of the key input parameters, sensitivity analysis was performed by varying each parameter one-at-a-time by 5 percent of its original value (Guinée et al., 2002).

\section{Life cycle costs}

The life cycle costing (LCC) methodology was applied for economic evaluation all costs of the life cycle of winter wheat production in the stages from "cradle-to-farm gate" (Rebitzer and Seuring, 2003). The set of data gathered for the purposes of the LCC analysis consisted of the cost items related to the inputs for the crop production such as fertilizers, plant protection products, seeds, agricultural machinery, fuel etc. The machinery costs included the costs of owning (depreciation, insurance and housing) and operating (repairs and maintenance, fuel, labour). The results of LCC analysis were expressed in monetary values (in euros) and referenced to the functional unit of 1 tonne of grain.

\section{Results and Discussion}

An inventory table of inputs was prepared in relation to the functional unit of 1 tonne of grain yield (Table 2). The seed rates in RT and DS were 10-11\% higher than in CT. The highest consumption of mineral fertilizers was found in wheat cultivated under DS (43.4 $\left.\mathrm{kg} \mathrm{NPK} \mathrm{t}^{-1}\right)$, followed by RT $\left(40.2 \mathrm{~kg} \mathrm{NPK} \mathrm{t}^{-1}\right)$. The most effective fertilization was in CT (23.6 kg NPK t ${ }^{-1}$ ). Total consumption of active substances (a.s.) in plant protection amounted to $0.26 \mathrm{~kg}, 0.30 \mathrm{~kg}$ and $0.22 \mathrm{~kg}$ per $1 \mathrm{t}$ of grain in CT, RT and DS, respectively. The highest levels of diesel oil consumed and agricultural machinery used were noted in RT despite foregoing energy-intensive ploughing. This is due to the fact that a modern, heavy equipment including high-powered tractors and multi-task machines with a large working width were mostly used in RT. Both the consumption of diesel oil and the use of agricultural machinery were the lowest in DS.

The results of LCA analysis for the life cycle of winter wheat production, based on the described system boundaries gave a total value of the carbon footprint indicator of $309.6 \mathrm{~kg}, 393.5 \mathrm{~kg}$ and $397.1 \mathrm{~kg} \mathrm{CO} 2$ eq. per $1 \mathrm{t}$ of grain for CT, RT and DS, respectively (Fig. 4). It should be noted that higher GHG emissions in DS and RT occured mainly due to higher nitrogen fertilizer inputs (Table 2). By taking into account the differences between the levels of GHG emissions and the SOC sequestration 
potential, estimated due to crop residues availability and soil tillage system, it was possible to assess the net value of the carbon footprint of wheat production. Contribution of SOC sequestration to the carbon footprint was mostly present in RT and DS, allowing to decrease the carbon footprint by $32 \%$ and $19 \%$, respectively. With regard to life cycle costs of wheat production, the highest cost was found for RT (EUR 105.4 $\mathrm{t}^{-1}$ ), followed by DS (EUR 97.6 $\mathrm{t}^{-1}$ ) and CT (EUR 76.0 $\mathrm{t}^{-1}$ ).

Table 2. Inventory data of main inputs and costs in winter wheat production under conventional tillage $(C T)$, reduced tillage $(R T)$ and direct sowing (DS) systems per functional unit of 1 tonne of grain

\begin{tabular}{c|c|c|c|c|c|c}
\hline \multirow{2}{*}{ Type of input } & \multicolumn{3}{|c|}{ Consumption per 1 t of grain } & \multicolumn{3}{c}{ Cost (EUR) per 1 t of grain } \\
\cline { 2 - 7 } & CT & RT & DS & CT & RT & DS \\
\hline Seeds (kg) & 25.0 & 27.8 & 27.5 & 10.8 & 12.0 & 11.6 \\
Nitrogen fertilizers (kg N) & 15.4 & 18.8 & 22.5 & 12.7 & 16.0 & 19.4 \\
Phosphorus fertilizers (kg P2 $\mathrm{O}_{5}$ ) & 3.49 & 6.95 & 5.05 & 3.0 & 6.9 & 4.7 \\
Potassium fertilizers (kg K2 $\mathrm{O}$ ) & 4.67 & 14.4 & 15.8 & 2.6 & 9.9 & 7.8 \\
Herbicides (kg a.s.) & 0.17 & 0.13 & 0.08 & 7.1 & 5.2 & 3.5 \\
Fungicides (kg a.s.) & 0.08 & 0.09 & 0.09 & 3.3 & 3.6 & 4.0 \\
Growth regulators (kg a.s.) & 0.01 & 0.08 & 0.05 & 0.4 & 3.2 & 2.2 \\
Agricultural machinery (kg) & 1.56 & 1.62 & 1.04 & 9.4 & 17.8 & 21.8 \\
Spare parts (kg) & 0.49 & 0.51 & 0.33 & 2.9 & 5.6 & 6.9 \\
Diesel oil (kg) & 12.6 & 14.8 & 9.14 & 14.8 & 17.9 & 10.8 \\
Lubricants (kg) & 0.50 & 0.59 & 0.36 & 3.4 & 4.0 & 2.4 \\
\hline
\end{tabular}

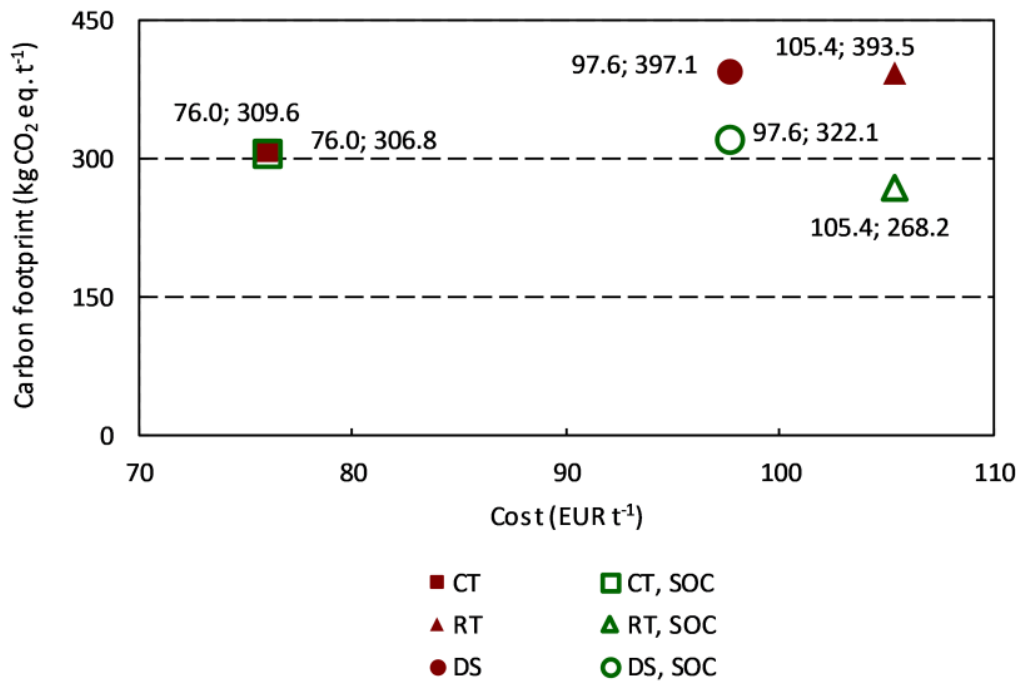

Figure 4. Combined results of the life cycle costs and carbon footprint of the winter wheat production under conventional tillage $(C T)$, reduced tillage $(R T)$ and direct sowing $(D S)(S O C$ - soil organic carbon changes included)

A similar result of the carbon footprint of wheat production was reported by Charles et al. (2006) (381 kg CO 2 eq. $\mathrm{t}^{-1}$ ). Studies in the Czech Republic showed that the GHG emission was higher, amounted to $558 \mathrm{~kg} \mathrm{CO}$ eq. per tonne of grain in wheat production under CT (Moudrý et al., 2013b). According to Sørensen et al. (2014) the total GHG emission per $\mathrm{t}$ of wheat grain was $655 \mathrm{~kg} \mathrm{CO}_{2}$ eq. for CT, $589 \mathrm{~kg} \mathrm{CO}_{2}$ eq. for 
RT and $628 \mathrm{~kg} \mathrm{CO}_{2}$ eq. for DS. In Finland, the differences in emissions between soil tillage systems were minor (Rajaniemi et al., 2011). Following these authors' explanation, if the carbon footprint assessment considers functional unit based on yield, the amount of GHG emissions per unit of grain is strongly dependent on the obtained yield size in the assessed system. Thus, the results of the impact assessment of crop production in different soil tillage systems may also be influenced by the differences in productivity achieved from these systems. In the presented study, the grain yield of wheat was lower in RT (by 9.2\%) and DS (by 13.2\%) compared to CT. Similar effects of soil tillage systems on wheat yields in the Wielkopolska region were observed by Panasiewicz et al. (2020). Townsend et al. (2016) stated that yield reductions in RT are small, suggesting that RT offers a realistic and attainable sustainable intensification of crop production. The level of the use of raw materials is an important determinant of the carbon footprint (Chiriaco et al., 2017). The production and use of nitrogen fertilizers contributes significantly to GHG emissions (Williams et al., 2010; Skowrońska and Filipek, 2014). Gan et al. (2014) showed that integrating improved practices such as fertilizing crops based on soil tests, reducing summer fallow frequencies and including grain legumes to rotation with cereals reduces the carbon footprint of spring wheat. It was also demonstrated that for each $\mathrm{kg}$ of grain produced, a net amount of 0.027-0.377 $\mathrm{kg} \mathrm{CO} 2$ eq. was captured from the atmosphere. In Danish studies, there were highlighted opportunities for carbon mitigation by incorporation of green manure crops (Knudsen et al., 2014). Wang and Dalal (2015) stated that implementation of no-till and stubble retention resulted in lower carbon footprint values.

Among the field operations, mineral fertilization was the major contributor to the total GHG emissions in three soil tillage systems (Fig. 5). Its share in the carbon footprint value was in the range from $72.5 \%$ for CT to $83.9 \%$ for DS. The soil cultivation and sowing also highly affected the carbon footprint, especially in the case of CT $(20.1 \%)$ due to high fuel consumption and use of agricultural machinery. The LCC analysis indicated that the soil cultivation and sowing resulted in a considerable part of life cycle costs of wheat production under CT (representing $41.3 \%$ of all costs). The total costs of RT and DS depended mainly on the fertilization $(38.1 \%$ and $42.7 \%$, respectively).

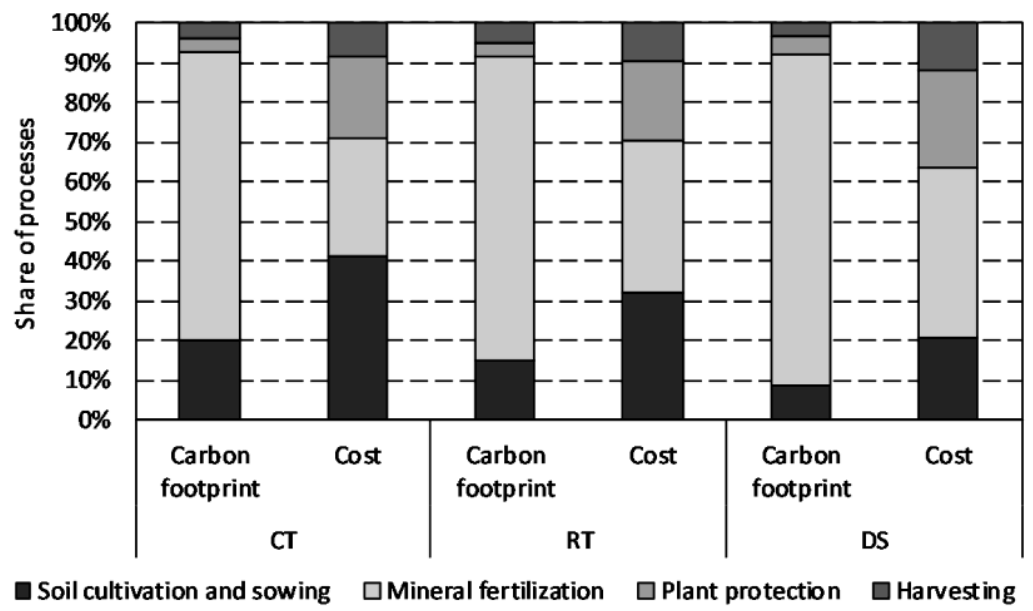

Figure 5. Contribution of field operations with associated inputs to the carbon footprint and costs of the winter wheat production under conventional tillage $(C T)$, reduced tillage $(R T)$ and direct sowing $(D S)$ 
Other authors also clearly identified that the mineral fertilization is responsible for a considerable part of GHG emissions from crop production (Brock et al., 2012; Mancuso et al., 2019). This is a concern in particular nitrogen fertilizers (Yan et al., 2015). In Lithuania, the costs of soil cultivation and sowing in CT were by 5 to $50 \%$ higher than those of various variants of RT systems and by up to 3.5 times higher than the costs of DS (Sarauskis et al., 2012). According to Townsend et al. (2016), despite lower fuel and machinery costs, unploughed tillage leads to additional crop protection costs resulting from a greater risk of weed, pest and disease burdens.

As shown in Figure 6, the highest cost and the largest carbon footprint associated with fuel consumption for the soil cultivation and wheat sowing was noted in CT. The fuel consumption in DS involved both least cost and GHG emissions. The use of machinery caused the highest cost and the largest GHG emissions in RT, while the least cost was in CT and the lowest carbon footprint was stated in DS.

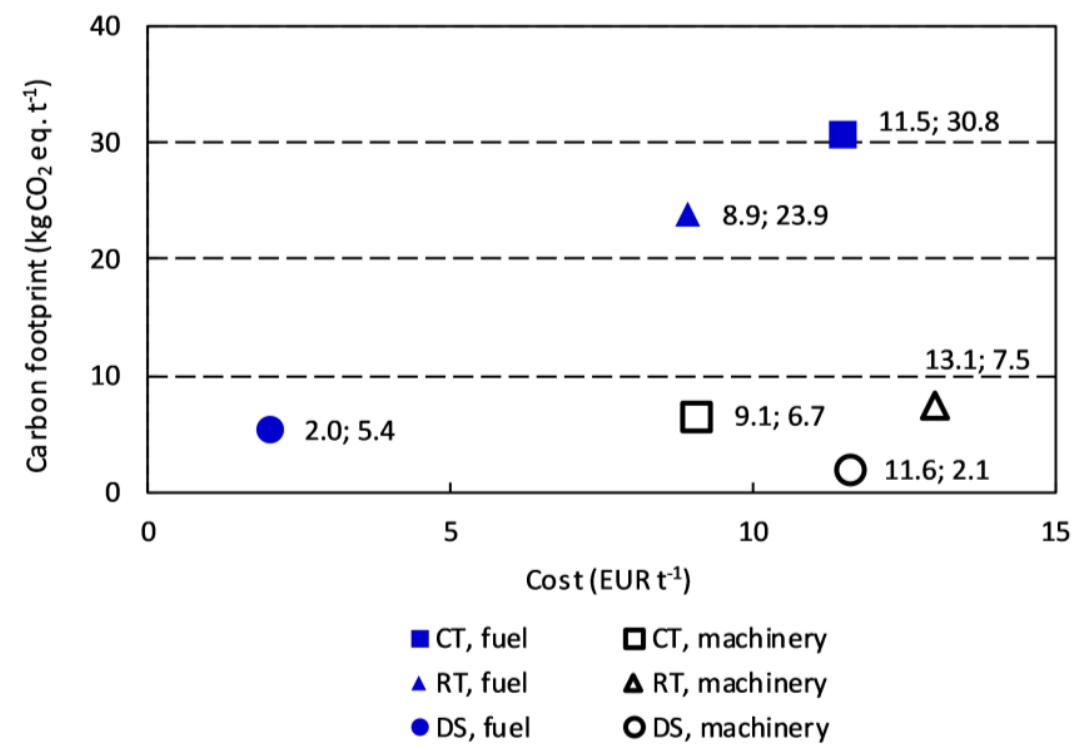

Figure 6. Combined results of the life cycle costs and the carbon footprint related to the fuel consumption and machinery use for the soil cultivation and wheat sowing under conventional tillage $(C T)$, reduced tillage $(R T)$ and direct sowing $(D S)$

Filipovic et al. (2006) showed that DS and RT due to lower fuel consumption for soil tillage ensured the reduction in GHG emission compared to CT. Positive effects of DS and RT on fuel savings and reduction of GHG emissions were also recorded by Stajnko et al. (2009) in studies on production of silage corn. Sørensen et al. (2014) stated that unploughed tillage generates savings in direct energy input and the amount of machinery items needed for soil tillage, thus it may lead to lower GHG emission. In studies by Sarauskis et al. (2012), the highest costs of cultivation and sowing in different tillage systems were found in small farms with areas of 2 ha. When the farm size was increased to 20 ha, the costs decreased.

In each soil tillage system, the pre-farm phase including manufacture and delivery of inputs for wheat production was more dominant in shaping the carbon footprint than the farm production phase. This also contributed more to the overall costs of the life cycle of wheat production (Fig. 7). 


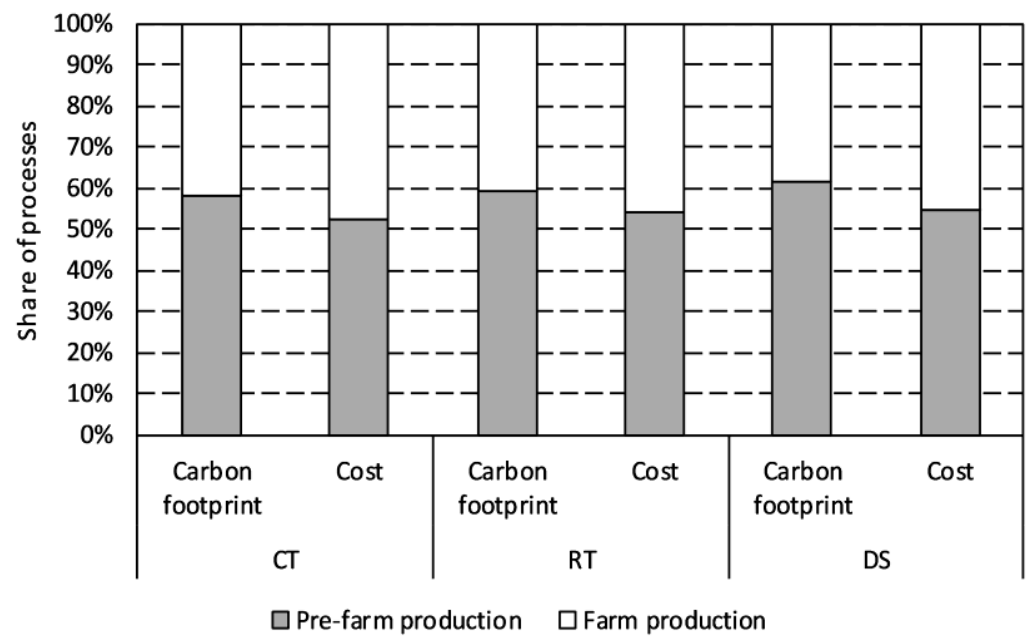

Figure 7. Carbon footprint and life cycle costs at pre-farm production and farm production life cycle phases of winter wheat under conventional tillage (CT), reduced tillage (RT) and direct sowing $(D S)$

Several studies also showed that the pre-farm production phase generated more GHG emissions than on-farm production (Biswas et al., 2008; Zhang et al., 2017). It should be stated that this results from a high share of energy- and material-consuming processes. Lares-Orozco et al. (2016) reported that the production of synthetic fertilizers accounted for $35 \%$ of the total emissions from the life cycle of wheat production. In life cycle of wheat production in Western Australia, GHG emissions from the production of fertilizers accounted for a significant portion of the impact for the pre-farm phase and the use of fertilizers was predominant for the on-farm phase (Biswas et al., 2008). Production of mineral fertilizers increases $\mathrm{GHG}$ emissions, mainly $\mathrm{CO}_{2}$ from fossil fuels used in production, while application of fertilizers contributes mostly to $\mathrm{N}_{2} \mathrm{O}$ emissions (Biswas et al., 2008; Skowrońska and Filipek, 2014).

Considering the results of sensitivity analysis of key input parameters for the carbon footprint, it can be concluded that the total amount of nitrogen $(\mathrm{N})$ fertilizers applied ranked as the most influential factor (Fig. 8). Varying $\mathrm{N}$ fertilizer application rate by $5 \%$ resulted in a change of total GHG emission from the life cycle of wheat by approximately $3.7 \%, 3.3 \%$ and $3.2 \%$ for DS, CT and RT, respectively. Fuel consumption was the second important factor for the carbon footprint. Phosphorus (P) and potassium (K) fertilizers, as well as agricultural machinery, had much less influence. The least sensitivity for the indicator resulted from the changes in the consumption of plant protection products.

As shown in Figure 9, the life cycle costs of wheat production in three soil tillage systems were the most sensitive to the change in the cost of the agricultural machinery. It should be noted that the life cycle costs of wheat under DS were more sensitive to the cost of machinery (1.5\%) than for wheat under RT and CT $(1.1 \%$ and $0.8 \%$, respectively). This is due to the fact that the cost of the machinery was the highest for DS. Varying the cost of fuel by $5 \%$ resulted in changes of life cycle cost of wheat by $0.9 \%, 0.8 \%$ and $0.5 \%$ for CT, RT and DS, respectively. The cost of $\mathrm{N}$ fertilizers was also an influential factor, especially in the case of life cycle costs of wheat under DS $(0.9 \%)$. Other cost items including cost of $\mathrm{P}$ and $\mathrm{K}$ fertilizers, cost of agricultural 
machinery and cost of plant protection products led to smaller changes in the life cycle costs of wheat production.

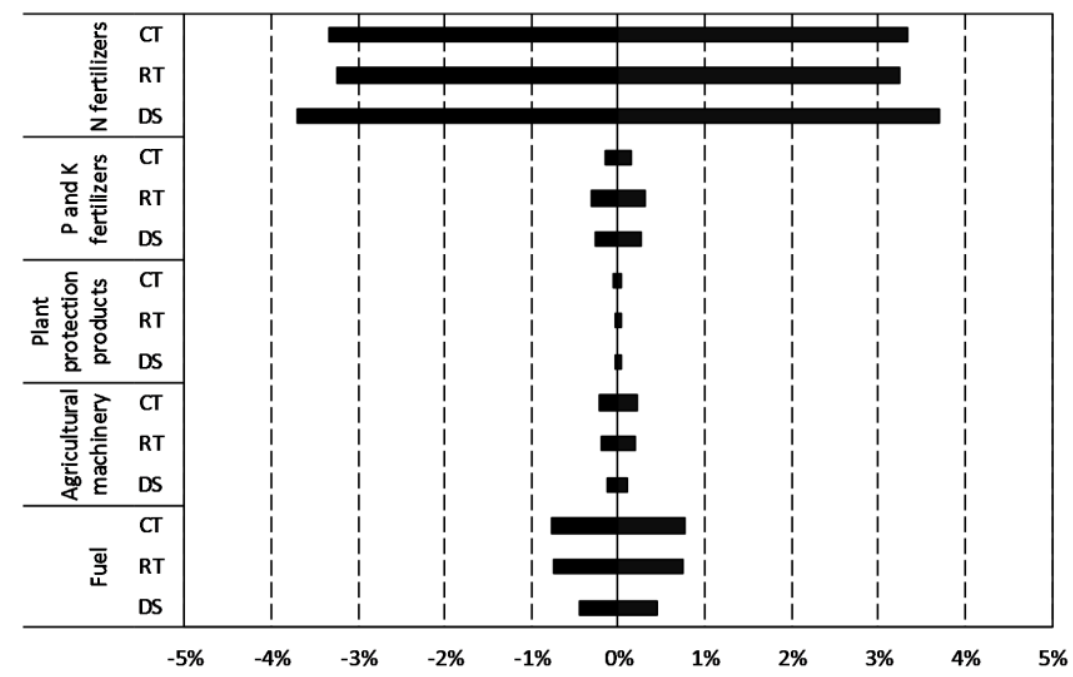

Figure 8. The sensitivity analysis of input parameters for the carbon footprint of the winter wheat production under conventional tillage $(C T)$, reduced tillage $(R T)$ and direct sowing $(D S)$

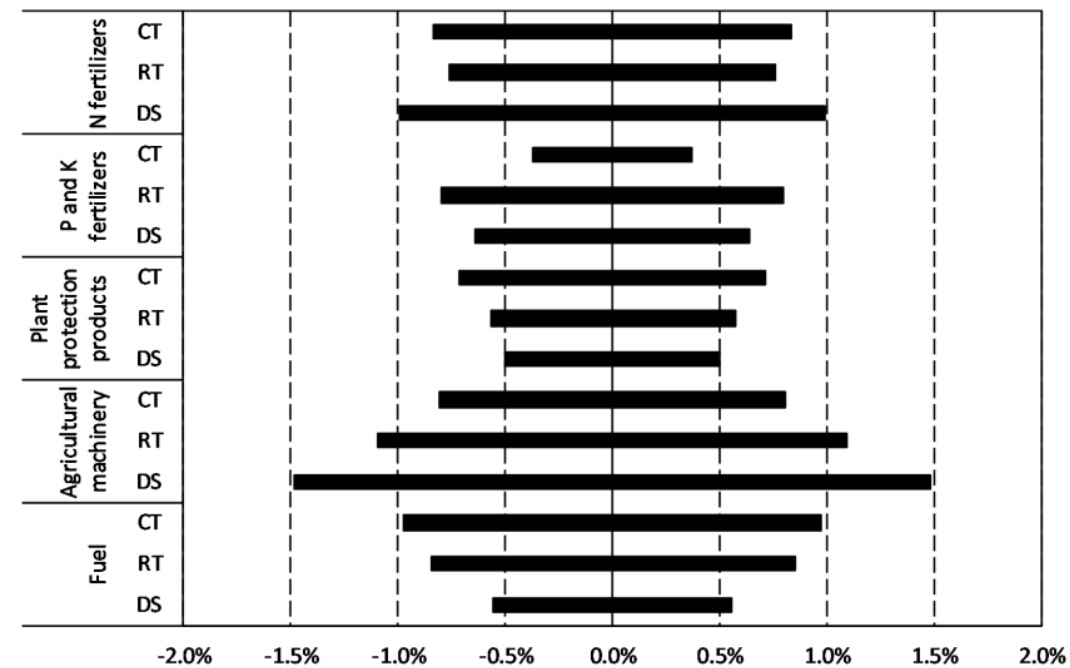

Figure 9. The sensitivity analysis of cost parameters for the life cycle costs of the winter wheat production under conventional tillage $(C T)$, reduced tillage $(R T)$ and direct sowing $(D S)$

\section{Conclusions}

Three soil tillage systems (conventional tillage, reduced tillage and direct sowing) for winter wheat production were compared with the use of carbon footprint and life cycle costs to present environmental and economic considerations. The research indicated that unploughed tillage combined with leaving large amounts of crop residues in the field and using catch crops leads to a lower size of the net carbon footprint in comparison with traditional tillage. Improvements in management of soil organic matter are 
important opportunities for the carbon footprint impact reduction. The potential for soil organic carbon retention can be increased by abandoning ploughing, growing cover crops and leaving crop residues in the field.

The fertilization process is a key factor driving the size of carbon footprint and life cycle costs of wheat production, independently from the soil tillage system. In conventional tillage, the soil cultivation and sowing provided a considerable share of the total carbon footprint and life cycle costs. Adoption of unploughed tillage systems is conducive to addressing climate change and achieving more eco-efficient performance.

The inclusion of environmental costs is recommended to be employed in future studies on the environmental burden of crop production with different tillage systems. Assessing the externalities of crop production and demonstrating the value of nature in economic terms is necessary to better inform political decision-makers and farmers to adopt practices that are more environmentally and economically sustainable.

Acknowledgements. The author would like to thank Dr Jerzy Bieńkowski, Institute for Agricultural and Forest Environment, Polish Academy of Sciences, for his valuable support in carrying out the work and Dr Tomasz Piechota, Poznań University of Life Sciences, for his contribution to preparing the photo presented in this paper. This study was carried out within the frame of the research project funded by the National Science Centre, Poland. Project no 2015/19/N/HS4/03031. Project title: "Environmental life cycle assessment and life cycle costing of grain crop production in different soil tillage systems".

\section{REFERENCES}

[1] Beddington, J. R., Asaduzzaman, M., Clark, M. E., Fernández Bremauntz, A., Guillou, M. D., Jahn, M. M., Lin, E., Mamo, T., Negra, C., Nobre, C. A., Scholes, R. J., Sharma, R., Van Bo, N., Wakhungu, J. (2012): The role for scientists in tackling food insecurity and climate change. - Agriculture and Food Security 1(1): 1-9.

[2] Biswas, W. K., Barton, L., Carter, D. (2008): Global warming potential of wheat produced in Western Australia: a life cycle assessment. - Water and Environment Journal 22(3): 206-216.

[3] Brock, P., Madden, P., Schwenke, G., Herridge, D. (2012): Greenhouse gas emissions profile for 1 tonne of wheat produced in Central Zone (East) New South Wales: A life cycle assessment approach. - Crop and Pasture Science 63(4): 319-329.

[4] BSI (2011): PAS 2050: Specification for the Assessment of the Life Cycle Greenhouse Gas Emissions of Goods and Services. - BSI, London.

[5] Caffrey, K. R., Veal, M. V. (2013): Conducting an agricultural life cycle assessment: challenges and perspectives. - The Scientific World Journal, Article ID: 472431.

[6] Campbell, B. M., Vermeulen, S. J., Aggarwal, P. K., Corner-Dolloff, C., Girvetz, E., Loboguerrero, A. M., Ramirez-Villegas, J., Rosenstock, T., Sebastian, L., Thornton, P. K., Wollenberg, E. (2016): Reducing risks to food security from climate change. - Global Food Security 11: 34-43.

[7] Charles, R., Jolliet, O., Gaillard, G., Pellet D. (2006): Environmental analysis of intensity level in wheat crop production using life cycle assessment. - Agriculture, Ecosystems and Environment 113(1-4): 216-225.

[8] Chiriaco, M. V., Grossi, G., Castaldi, S., Valentini, R. (2017): The contribution to climate change of the organic versus conventional wheat farming: a case study on the carbon footprint of wholemeal bread production in Italy. - Journal of Cleaner Production 153: 309-319.

[9] Cihelková, E. (2011): Climate change in the context of global environmental governance possibilities. - Agricultural Economics 57(9): 436-448. 
[10] Cooper, J., Butler, G., Leifert, C. (2011): Life cycle analysis of greenhouse gas emissions from organic and conventional food production systems, with and without bio-energy options. - NJAS - Wageningen Journal of Life Sciences 58(3-4): 185-192.

[11] CSO (2012): Characteristics of agricultural holdings - National Agricultural Census 2010. - CSO, Warsaw.

[12] EC (2014): A policy framework for climate and energy in the period from 2020 to 2030 (COM/2014/015 final). - Communication from the Commission to the European Parliament, the Council, the European Economic and Social Committee and the Committee of the Regions. EC, Brussels.

[13] EEA (2013): EMEP/EEA air pollutant emission inventory guidebook 2013. Publications Office of the European Union, Luxembourg.

[14] EEA (2016): EMEP/EEA air pollutant emission inventory guidebook 2016. Publications Office of the European Union, Luxembourg.

[15] EEA (2019): Climate change adaptation in the agriculture sector in Europe. EEA Report 4. - https://www.eea.europa.eu/publications/cc-adaptation-agriculture.

[16] Eurostat (2018): Agri-environmental indicator - tillage practices. Statistics Explained. https://ec.europa.eu/eurostat/statistics-explained/index.php?title=Agrienvironmental_indicators.

[17] FAO (2019): World food and agriculture - Statistical Pocketbook 2019. - FAO, Rome.

[18] Filipovic, D., Kosutic, S., Gospodaric, Z., Zimmer, R., Banaj, D. (2006): The possibilities of fuel savings and the reduction of $\mathrm{CO}_{2}$ emissions in the soil tillage in Croatia. Agriculture, Ecosystems and Environment 115(1-4): 290-294.

[19] Gan, Y., Liang, C., Chai, Q., Lemke, R. L., Campbell, C. A., Zentner, R. P. (2014): Improving farming practices reduces the carbon footprint of spring wheat production. Nature Communications 5: 1-13.

[20] Guardia, G., Tellez-Rio, A., García-Marco, S., Martin-Lammerding, D., Tenorio, J. L., Ibáñez, M. A., Vallejo, A. (2016): Effect of tillage and crop (cereal versus legume) on greenhouse gas emissions and Global Warming Potential in a non-irrigated Mediterranean field. - Agriculture, Ecosystems and Environment 221(1): 187-197.

[21] Guinée, J. B., Gorrée, M., Heijungs, R., Huppes, G., Kleijn, R., de Koning, A., van Oers, L., Wegener Sleeswijk, A., Suh, S., Udo de Haes, H. A., de Bruijn, H., van Duin, R., Huijbregts, M. A. J. (2002): Handbook on life cycle assessment. Operational guide to the ISO standards. I: LCA in perspective. IIa: Guide. IIb: Operational annex. III: Scientific background. - Kluwer Academic Publishers, Dordrecht.

[22] Harasim, A. (2002): Comprehesive assessment of rotations with different percentage of cereal and root crops. - Monografie i Rozprawy Naukowe, IUNG, Puławy. (in Polish).

[23] Hillier, J., Hawes, C., Squire, G., Hilton, A., Wale, S., Smith, P. (2009): The carbon footprints of food crop production. - International Journal of Agricultural Sustainability 7(2): 107-118.

[24] IPCC (2006): IPCC Guidelines for national greenhouse gas inventories. - Institute for Global Environmental Strategies, Hayama.

[25] IPCC (2007): Climate change 2007. The physical science basis. - Contribution of Working Group I to the Fourth Assessment Report of the Intergovernmental Panel on Climate Change, Cambridge University Press, Cambridge.

[26] Kanianska, R. (2016): Agriculture and its impact on land-use, environment, and ecosystem services. - In: Almusaed, A. (ed.) Landscape ecology. The influences of land use and anthropogenic impacts of landscape creation. IntechOpen, London.

[27] Knudsen, M. T., Meyer-Aurich, A., Olesen, J. E., Chirinda, N., Hermansen, J. E. (2014): Carbon footprints of crops from organic and conventional arable crop rotations - using a life cycle assessment approach. - Journal of Cleaner Production 64: 609-618.

[28] Kowalski, Z., Kulczycka, J., Góralczyk, M. (2007): Ecological life cycle assessment of manufacturing processes. - PWN, Warsaw. (in Polish). 
[29] Lares-Orozco, M. F., Robles-Morúa, A., Yepez, E. A., Handler, R. M. (2016): Global warming potential of intensive wheat production in the Yaqui Valley, Mexico: a resource for the design of localized mitigation strategies. - Journal of Cleaner Production 127: $522-532$

[30] Liu, C., Cutforth, H., Chai, Q., Gan, Y. (2016): Farming tactics to reduce the carbon footprint of crop cultivation in semiarid areas. A review. - Agronomy for Sustainable Development 36: 1-16.

[31] Loboguerrero, A. M., Campbell, B. M., Cooper, P. J. M., Hansen, J. W., Rosenstock, T., Wollenberg, E. (2019): Food and earth systems: priorities for climate change adaptation and mitigation for agriculture and food systems. - Sustainability 11(5): 1-26.

[32] Mancuso, T., Verduna, T., Blanc, S., Di Vita, G., Brun, F. (2019): Environmental sustainability and economic matters of commercial types of common wheat. Agricultural Economics 65(4): 194-202.

[33] Morris, N., Miller, P., Orson, J. H., Froud-Williams, R. (2010): The adoption of noninversion tillage systems in the United Kingdom and the agronomic impact on soil, crops and the environment - a review. - Soil and Tillage Research 108(1): 1-15.

[34] Moudrý, J. Jr., Jelínková, Z., Jarešová, M., Plch, R., Moudrý, J., Konvalina, P. (2013a): Assessing greenhouse gas emissions from potato production and processing in the Czech Republic. - Outlook on Agriculture 42(3): 179-183.

[35] Moudrý, J. Jr., Jelínková, Z., Plch, R., Moudrý, J., Konvalina, P., Hyšpler, R. (2013b): The emissions of greenhouse gases produced during growing and processing of wheat products in the Czech Republic. - Journal of Food, Agriculture and Environment 11(1): 1133-1136.

[36] Panasiewicz, K., Faligowska, A., Szymańska, G., Szukała, J., Ratajczak, K., Sulewska, H. (2020): The effect of various tillage systems on productivity of narrow-leaved lupinwinter wheat-winter triticale-winter barley rotation. - Agronomy 10(2): 1-11.

[37] Pandey, D., Agrawal, M., Pandey, J. S. (2011): Carbon footprint: current methods of estimation. - Environmental Monitoring and Assessment 178: 135-160.

[38] Petersen, B., Knudsen, M., Hermansen, J., Halberg, N. (2013): An approach to include soil carbon changes in life cycle assessments. - Journal of Cleaner Production 52: 217224.

[39] PKN (2006): PN-EN ISO 14040. Environmental management. Life cycle assessment. Principles and framework. - PKN, Warsaw. (in Polish).

[40] PKN (2009): PN-EN ISO 14044. Environmental management. Life cycle assessment. Requirements and guidelines. - PKN, Warsaw. (in Polish).

[41] Rajaniemi, M., Mikkola, H., Ahokas, J. (2011): Greenhouse gas emissions from oats, barley, wheat and rye production. - Agronomy Research, Biosystem Engineering 1: 189195.

[42] Rebitzer, G., Seuring, S. (2003): Methodology and application of life cycle costing. International Journal of Life Cycle Assessment 8: 110-111.

[43] Sarauskis, E., Buragienè, S., Romaneckas, K., Sakalauskas, A., Algirdas, J., Vaiciukevicius, E., Karayel, D. (2012): Working time, fuel consumption and economic analysis of different tillage and sowing systems in Lithuania. - Engineering for Rural Development 11: 52-59.

[44] Skowrońska, M., Filipek, T. (2014): Life cycle assessment of fertilizers: A review. International Agrophysics 28: 101-110.

[45] Sørensen, C. G., Halberg, N., Oudshoorn, F. W., Petersen, B. M., Dalgaard, R. (2014): Energy inputs and GHG emissions of tillage systems. - Biosystems Engineering 120: 214.

[46] Stajnko, D., Lakota, M., Vučajnk, F., Bernik, R. (2009): Effects of different tillage systems on fuel savings and reduction of $\mathrm{CO}_{2}$ emissions in production of silage corn in eastern Slovenia. - Polish Journal of Environmental Studies 18(4): 711-716. 
[47] Townsend, T. T., Ramsden, S. J., Wilson, P. (2016): Analysing reduced tillage practices within a bio-economic modelling framework. - Agricultural Systems 146: 91-102.

[48] UNEP (2010): Assessing the environmental impacts of consumption and production: priority products and materials. A report of the working group on the environmental impacts of products and materials to the international panel for sustainable resource management. $\quad-\quad$ http://www.unep.fr/shared/publications/pdf/DTIx1262xPAPriorityProductsAndMaterials_Report.pdf.

[49] Vach, M., Strašil, Z., Javurek, M. (2016): Economic efficiency of selected crops cultivated under different technology of soil tillage. - Scientia Agriculturae Bohemica 47(1): 40-46.

[50] Van Beek, C. L., Brouwer, L., Oenema, O. (2003): The use of farmgate balances and soil surface balances as estimator for nitrogen leaching to surface water. - Nutrient Cycling in Agroecosystems 67: 233-244.

[51] Vermeulen, S. J., Campbell, B. M., Ingram, J. S. I. (2012): Climate change and food systems. - Annual Review of Environment and Resources 37: 195-222.

[52] Wandel, J., Smithers, J. (2000): Factors affecting the adoption of conservation tillage on clay soils in Southwestern Ontario, Canada. - American Journal of Alternative Agriculture 15: 181-188.

[53] Wang, W., Dalal, R. C. (2015): Nitrogen management is the key for low-emission wheat production in Australia: A life cycle perspective. - European Journal of Agronomy 66: 74-82.

[54] Weidema, B. P., Thrane, M., Christensen, P., Schmidt, J., Løkke, S. (2008): Carbon Footprint - a catalyst for LCA? - Journal of Industrial Ecology 12(1): 3-6.

[55] Williams, A., Audsley, E., Sandars, D. (2010): Environmental burdens of producing bread wheat, oilseed rape and potatoes in England and Wales using simulation and system modelling. - International Journal of Life Cycle Assessment 15: 855-868.

[56] Yan, M., Cheng, K., Luo, T., Yan, Y., Pan, G., Rees, R. M. (2015): Carbon footprint of grain crop production in China - based on farm survey data. - Journal of Cleaner Production 104: 130-138.

[57] Zhang, D., Shen, J., Zhang, F., Li, Y., Zhang, W. (2017): Carbon footprint of grain production in China. - Scientific Reports 7: 1-11. 